\title{
Globalization and the Changing Epidemiology of Hepatitis A Virus
}

\author{
Kathryn H. Jacobsen \\ College of Health and Human Services, George Mason University, Fairfax, Virginia 22030 \\ Correspondence: kjacobse@gmu.edu
}

Increased economic interdependence, social integration, and other aspects of globalization are contributing to significant changes in hepatitis A epidemiology. Globally, the incidence of hepatitis A virus (HAV) infection is decreasing, the age at midpoint of population immunity (AMPI) is increasing, and the proportion of symptomatic cases is increasing as the average age at infection increases. In low-income countries, HAV remains endemic but improved water and sanitation systems are reducing transmission rates among young children. In high-income countries, most adults remain susceptible to HAV and foodborne outbreaks are becoming more frequent. Middle-income countries have diverse epidemiological profiles, and they play important roles in the global spread of HAV through international trade and travel. Future changes in the epidemiology of hepatitis A will be heavily influenced by globalization processes.

\begin{abstract}
Clobalization is a process characterized by $\checkmark$ countries and people around the world becoming more interdependent and integrated across economic, political, cultural, and other domains. Evidence for globalization can be observed in the increasing rates of cross-border trade, the growing complexity of international supply chains, the rising pace of international travel and migration, and the social and cultural changes that are occurring as online communication makes it easy for people from different parts of the world to interact. The globalization of economic markets and sociocultural practices is influencing human behaviors, altering the ways people interact socially and with the environment, and modifying the ways people conceive of health and seek health services (Huynen
\end{abstract}

et al. 2005). For infectious diseases generally, and for hepatitis A specifically, the globalization of trade and travel are important drivers of epidemiological change (Suk et al. 2014; Semenza et al. 2016).

This article summarizes the current epidemiology of hepatitis A in countries with different income levels and endemicity patterns, describes the major socioeconomic and environmental changes that are contributing to hepatitis A epidemiological transitions, examines the specific roles of international food trade and international travel on hepatitis A epidemiology, and uses globalization theory to predict the changes that are likely to occur in hepatitis A epidemiology over the next several decades.

Editors: Stanley M. Lemon and Christopher Walker

Additional Perspectives on Enteric Hepatitis Viruses available at www.perspectivesinmedicine.org

Copyright (C) 2018 Cold Spring Harbor Laboratory Press; all rights reserved; doi: 10.1101/cshperspect.a031716

Cite this article as Cold Spring Harb Perspect Med 2018;8:a031716 
K.H. Jacobsen

\section{HEPATITIS A VIRUS (HAV) EPIDEMIOLOGY}

Tens of millions of individuals worldwide contract HAV through fecal-oral transmission each year, usually via ingestion of contaminated food or water or through contact with an infectious person (Rein et al. 2014). Young children who are exposed to the virus usually have no symptoms of disease, but older children and adults often experience several weeks of jaundice and a lengthy convalescence, and they are at risk of acute liver failure and death. Symptomatic hepatitis A patients typically miss several weeks of work or school, and the costs of medical care can be substantial (Berge et al. 2000). Globally, the $\mathrm{HAV}$ incidence rate is decreasing and the average age at infection is increasing (Rein et al. 2014). However, there are major differences in the profiles of countries with different socioeconomic profiles (Jacobsen 2009).

Low-income countries typically have high HAV incidence rates. Surveillance for incident hepatitis A cases can be difficult in high-incidence areas because the majority of cases occur in young children who remain asymptomatic. However, even asymptomatic infections confer long-term immunity against HAV that can be detected with serologic tests. Seroprevalence studies in low-income countries typically show that nearly $100 \%$ of older children and adults have anti-HAV immunoglobulin (Ig)G levels indicating prior infection with HAV and that the majority of young children already have serologic evidence of past infection (Jacobsen 2009). The age at midpoint of population immunity (AMPI) is the youngest age at which half of the birth cohort has serologic evidence of prior exposure to HAV. In most sub-Saharan African countries and other very low-income areas, the AMPI is less than 5 years (Jacobsen and Wiersma 2010), which means that more than half of preschool-aged children have already contracted HAV and developed immunity as a result of their infection. These prevalence statistics in children provide ample evidence of high $\mathrm{HAV}$ incidence rates in low-income countries.

High-income countries usually have low or very low HAV incidence rates, and seroprevalence studies typically show an AMPI that is in middle adulthood. For example, in many Western and Northern European countries, the AMPI is above 50 years, which means that more than half of 50-year-olds and the vast majority of children and younger adults remain susceptible to HAV infection (Kurkela et al. 2012; Carrillo-Santisteve et al. 2017). When a large proportion of hepatitis A cases occur among adolescents and adults, the case detection rate is usually fairly high because nearly all infected individuals in these age groups develop jaundice. A reasonable estimation of the annual $\mathrm{HAV}$ incidence rate can be calculated from mandatory notifications of cases to public health authorities. When outbreaks occur and the incidence rate spikes, these situations often can be detected soon after the first cases become symptomatic. Even outbreaks that spread through childcare facilities usually can be detected, because caregivers who contract the virus from asymptomatic infected children are likely to develop jaundice after the 15- to 50-day incubation period (Staes et al. 2000). However, the long incubation period, averaging about 4 weeks, means that it is often difficult for investigators to identify the specific original source of HAV outbreaks.

In middle-income countries in which incomes are rising, urbanization is occurring, and nearly all members of the population (especially in urban areas) now have access to clean water, the incidence of HAV is decreasing and the median age at infection is rising. Significant increases in the AMPI were observed between 1990 and 2005 in East Asia, Southeast Asia, Eastern and Central Europe, Latin America, and parts of the Middle East and North Africa (Jacobsen and Wiersma 2010). Paradoxically, a lower HAV incidence rate often initially causes an increase in the number of hospitalizations and deaths from hepatitis $\mathrm{A}$ in the population, because older hepatitis A patients tend to be much sicker than young children who become infected. Mathematical models of HAV in uppermiddle-income countries, like Brazil, Mexico, and Thailand, have found that a decrease from an intermediate to a low overall incidence rate may not have a significant impact on reducing the rate of symptomatic disease for several de- 
cades, in the absence of vaccination, because the proportion of symptomatic cases increases as the overall incidence rate decreases (Van Effelterre et al. 2017a,b). However, these countries are expected to eventually shift to the lowincidence, nonendemic profiles currently observed in high-income countries. This transition has already occurred in many upper-middle-income countries.

\section{RISK FACTORS FOR HAV}

$\mathrm{HAV}$ incidence rates are decreasing in most countries. Many high-income countries are now nonendemic for HAV, many middle-income countries are shifting from intermediate to low endemicity, and many low-income countries are shifting from very high to high or intermediate endemicity (Jacobsen and Koopman 2005). Several factors are influencing these changes in HAV epidemiology.

One contributor is improved access to clean drinking water sources and to sanitation and hygiene facilities. The incidence of HAV decreases when everyone in a community has access to a toilet and a handwashing facility, especially food handlers, caregivers of young children who are not yet toilet-trained, and others who are at elevated risk of playing a role in the transmission of HAV within communities. Meta-analysis has confirmed the association between higher rates of access to a safe drinking water source and a lower HAV incidence rate (Jacobsen and Koopman 2005). Hepatitis A has an unusual risk profile because a lower incidence rate can raise the number of symptomatic cases occurring in a population by postponing the age at which the typical individual contracts the virus. This characteristic of the disease means that increased access to water and sanitation can initially increase the population burden from HAV (Mohd Hanafiah et al. 2011), although the case numbers will decrease as continued infrastructure development further reduces the incidence rate.

Water and sanitation access do not adequately explain the differences in HAV endemicity levels between countries with moderate or high water-access rates. In these locations, economic indicators such as the gross national income per capita or the human development index (which combines economic, education, and life expectancy data into one metric) appear to be better predictors of HAV endemicity than water access (Itani et al. 2014; Koroglu et al. 2017). This relationship between socioeconomic status and HAV risk is also observed at the individual and household levels, with higher incomes, higher levels of education, smaller family sizes and less crowding in the home, and other indicators of higher socioeconomic status associated with a reduced likelihood of exposure to HAV (Jacobsen and Koopman 2004). Thus, socioeconomic development appears to be a factor in changing HAV epidemiology trends in ways that extend beyond environmental improvements.

Another set of factors relates to human demographics. One important driver of HAV epidemiology in middle-income countries appears to be rural-to-urban migration (Van Effelterre et al. 2017a). Rural areas tend to be poorer and have less developed water and sanitation infrastructure, so they tend to have higher HAV incidence and prevalence rates (Jacobsen and Koopman 2004). When a rural resident of a middle-income country who is shedding HAV as a result of acute infection travels to a city, that infectious individual may infect many urban residents who are susceptible to $\mathrm{HAV}$, especially if the rural resident is in the city to sell produce or other food items.

A similar process may occur in higher-income countries as a result of refugee migration. Child refugees originating in places with intermediate or high HAV endemicity who contract HAV at the start of their journey or during their travels may become contagious several weeks later, after the family has relocated to a new country. If the housing available to refugees is substandard and residents do not have sufficient access to hygiene facilities, one infected child may spark an outbreak within the refugee community. Outbreaks have occurred recently in several refugee camps in Europe that are hosting people who have fled from the conflict in Syria, including camps in Germany and Greece (Mellou et al. 2017; Michaelis et al. 2017). These outbreaks have generally remained within the 
K.H. Jacobsen

refugee community, and vaccination strategies have been successful at preventing spread to other local populations (Mellou et al. 2017; Michaelis et al. 2017). However, it is possible for migrants and other travelers to initiate chains of local transmission of HAV in low-endemicity countries.

An additional demographic process influencing HAV epidemiological patterns is population aging. In nations designated as "least developed countries," young children who are not yet toilet-trained account for up to $10 \%$ of the total population; in high-income countries, this proportion is usually about $3 \%$ (UN DESA 2017). In communities with a relatively large proportion of young children in their populations, child-tochild transmission plays a key role in sustaining endemic levels of hepatitis A. Countries with older populations rarely have endemic HAV, but they are vulnerable to outbreaks of hepatitis A because a sizeable proportion of their residents remain susceptible to HAV.

Globalization may play a role in all of these risk scenarios. In particular, economic globalization processes are enabling financial and infrastructural development in many parts of the world and are driving increased rural-to-urban and international migration and trade. For hepatitis $\mathrm{A}$, international food trade and greater human mobility are critical components of the epidemiological changes that are occurring globally.

\section{HAV AND INTERNATIONAL FOOD TRADE}

In low-income countries, HAV is spread through contaminated water, direct contact with infectious individuals, and consumption of contaminated foods. Because these transmission pathways all relate to water, sanitation, and hygiene, it may be impossible to isolate the particular exposure responsible for causing a cluster of hepatitis A cases. In high-income countries, where safe drinking water is routinely available, it is more feasible to identify the specific food items that cause outbreaks. The two primary food groups linked to outbreaks of hepatitis A are produce and seafood (Greig and Ravel 2009), including frozen berries, green onions, lettuce, oysters, clams, and mussels (Acheson and Fiore 2004). The World Health Organization's Foodborne Disease Burden Epidemiology Reference Group estimated that more than 90,000 people worldwide died of hepatitis A disease in 2010 and that nearly 30,000 of those deaths could be directly attributed to foodborne acquisition of HAV (Kirk et al. 2015).

Although most foodborne outbreaks of hepatitis A are small, affecting only a few dozen or several hundred people, these outbreaks can become widespread. In 1988, nearly 300,000 people in Shanghai contracted HAV by eating raw clams, a popular delicacy that had been consumed by nearly one-third of the city's residents in the month before the outbreak began (Halliday et al. 1991). In 2003, more than 600 people contracted HAV from a single restaurant in Pennsylvania, in the United States, by eating contaminated green onions that had been imported from Mexico (Wheeler et al. 2005).

International trade in foods is accelerating. For example, in the United States, the proportion of consumed food that is imported from other countries increased from 12\% in 1990 to $20 \%$ in 2013 ; this proportion increased from $56 \%$ to $97 \%$ for fish and shellfish, from $31 \%$ to $49 \%$ for fruits and nuts, and from $4 \%$ to $20 \%$ for vegetables (Jerardo 2016). The number of foodborne outbreaks in the United States rose steadily as the proportion of food that is imported increased (Gould et al. 2017). Although not all foodborne outbreaks of hepatitis A in high-income countries are caused by imported foods, the risk of HAV contamination is elevated when foods are procured from low- or middle-income countries that are HAV-endemic.

Globalization is expected to increase the number of foodborne outbreaks in high-income countries, and there is already evidence of this change occurring. For example, frozen berries have caused numerous outbreaks of hepatitis A in Europe. In one large outbreak that occurred between January 2013 and August 2014, more than 1100 people in Italy, Germany, Norway, and 10 other European countries were hospitalized with hepatitis A disease. Some of the cases were travelers to Italy, but most were people who had not traveled outside of their home countries 
in the months before they became ill. Molecular characterization and trace-back investigations linked the outbreak to Bulgarian blackberries and Polish red currants that had been added to mixed berry products (Severi et al. 2015). Bulgaria is classified as an upper-middle-income country, unlike its high-income neighbors, and the $86 \%$ rate of access to improved sanitation facilities in Bulgaria in 2015 was considerably lower than the 99\% European average (UNICEF/ WHO 2015). The fruit products likely became contaminated as a result of poor worker hygiene or the spraying of produce with irrigation water that contained raw sewage (Tavoschi et al. 2015). At the same time that this large outbreak was occurring, separate multicountry hepatitis A outbreaks in other parts of Europe were linked to strawberries imported from Egypt and Morocco (Gossner and Severi 2014). Foodborne outbreaks of HAV in other parts of the world have also been reported with increasing frequency. A multistate outbreak in the United States in 2013 was attributed to imported frozen pomegranate arils from Turkey, which is classified as an upper middle-income country (Collier et al. 2014). Pomegranate seeds from Egypt were implicated in an HAV outbreak in Canada in 2012 (Swinkels et al. 2014). Hundreds of Australians contracted HAV from imported sundried and semidried tomatoes in 2009, and the same strain also caused a tomato-borne outbreak in the Netherlands in 2009-2010 (Donnan et al. 2012).

Preventing HAV cases caused by imported foods requires improving food-processing practices in source countries. Globalization provides opportunities to establish, strengthen, and enforce international food safety regulations and to improve information sharing about hazards (Käferstein et al. 1997). Strategies for reducing the threat from foodborne infections usually require both exporting and importing countries to be willing to invest resources in supporting enhanced food protections. Corporations involved in international food production, manufacturing, and trade can also be incentivized to take steps to better guarantee the quality and safety of food products. Without improvements, many residents of high- and middle-income countries face an increasing risk of contracting HAV from food products as global food trade accelerates.

\section{HAV AND INTERNATIONAL TRAVEL}

Modern transportation networks and other developments stemming from the globalization of human movement have enabled infectious diseases to spread more quickly across international borders (Gushulak and MacPherson 2000). The number of international trips increased from 25 million worldwide in 1950 to 278 million in 1980, 674 million in 2000, and 1186 million in 2015; this number is projected to reach 1.8 billion trips per year by 2030 (UNWTO 2016). These trips are distributed across the globe. In 2015 , about $51 \%$ of international destinations were European countries, 24\% were in the Asia-Pacific region, $16 \%$ were in the Americas, 5\% were in Africa, and 5\% were in the Middle East (UNWTO 2016).

Hepatitis A is one of the vaccine-preventable diseases that is most common among tourists and other international travelers (Boggild et al. 2010). The majority of travel-associated hepatitis A cases occur when residents of high-income countries (and some urban residents from middle-income countries) travel to places with higher levels of HAV endemicity. Unvaccinated travelers may contract the virus and then become ill after they have returned to their home countries. These imported viral infections may then be transmitted within households, schools, workplaces, and other social networks, and those secondary cases may cause subsequent waves of transmission. The accelerated rates of global travel that are projected to occur in the coming years could increase the number of travel-associated outbreaks in high-income and middleincome countries.

Hepatitis A vaccines can protect travelers from nonendemic and low-endemicity countries who are likely to be exposed to HAV during trips to HAV-endemic locations. An added benefit is that vaccinated travelers will not bring HAV home and cause secondary cases in nontraveling contacts. Vaccination is typically recommended for high-risk populations from high-income countries, including travelers to 
K.H. Jacobsen

higher endemicity areas as well as, in some situations, immunocompromised individuals, men who have sex with men, people who inject drugs, and healthcare workers (ACIP 2006; WHO 2012; Gossner et al. 2015). However, too many travelers are unaware of the recommendations for hepatitis A vaccination or choose to disregard advice from health professionals and other information sources. A study of people from Australia, Canada, Finland, Germany, Norway, Sweden, and the United Kingdom who were traveling to HAV-endemic countries found that a large minority of travelers had never been vaccinated against hepatitis A (Heywood et al. 2016). Hepatitis A vaccination rates have also been found to be low among travelers from Japan (Namikawa et al. 2010) and suboptimal among travelers from France, Italy, South Korea, Spain, and the United States (Chin et al. 2016; Pedersini et al. 2016; Lammert et al. 2017).

Of the cases of hepatitis $A$ in international travelers reported between 2007 and 2011 to GeoSentinel, the global surveillance network of the International Society of Travel Medicine (ISTM), which is operated in partnership with the U.S. Centers for Disease Control and Prevention (CDC), about half of the cases were tourists engaging in leisure travel to India, Morocco, Egypt, Mexico, or other locations, about $10 \%$ were traveling for business, and about onethird were people visiting friends or relatives (VFRs) in another country (Leder et al. 2013). The VFR designation typically refers to foreignborn individuals and their children who return to the migrants' countries of origin to visit their extended families (Barnett et al. 2010). The majority of people who resettle in a new country move from a middle-income country to a highincome country (UN DESA 2016). Immigrants from places with endemic HAV will have developed natural immunity to HAV as children following asymptomatic infection, and they may not realize that their offspring who were born and raised in nonendemic areas are vulnerable to HAV and could become very ill from the virus. VFRs are significantly less likely than nonVFR travelers to be protected against HAV through vaccination, and they are more likely to report engaging in risky behaviors such as drinking tap water and eating raw shellfish (van Genderen et al. 2012). The risks of undervaccination of VFRs, especially children and adolescents, are apparent in travel health reports. For example, more than half of hepatitis A cases among returning international travelers living in Quebec between 2004 and 2007 were VFRs, and the majority of those cases were pediatric infections even though children accounted for only about $10 \%$ of VFRs (Bui et al. 2011).

International tourism is a sizeable proportion of the global economy, generating more than $\$ 1.2$ trillion in spending each year (UNWTO 2016). Nearly $40 \%$ of this spending -about $\$ 500$ billion-is expended in low- and middle-income countries, and travel is an important part of the economic growth strategies in many of these destinations. The proportion of international travelers heading to a low- or middle-income country is expected to grow over the coming decades (UNWTO 2016). As the proportion and number of travelers from higher-income countries who remain susceptible to HAV increase, the number of international travelers who contract HAV while abroad may increase.

\section{HEPATITIS A PREDICTIONS FOR A GLOBALIZING WORLD}

A map showing the estimated AMPI for each country worldwide in 2015 is presented in Figure 1. AMPI values derived from serological studies are available for many countries in Europe (Carrillo-Santisteve et al. 2017) and the Middle East (Koroglu et al. 2017) as well as for Argentina (Yanez et al. 2014), Brazil (Ximenes et al. 2014), China (Lu et al. 2009), Mexico (Lazcano-Ponce et al. 2013), South Korea (Lee et al. 2011), Thailand (Sa-nguanmoo et al. 2016), the United States (Klevens et al. 2011), and several other locations. For countries without recent population-based surveys of hepatitis A seroprevalence rates by age, an estimated AMPI value was imputed based on the country's human development index and other socioeconomic and environmental indicators. Limited data availability means that there is uncertainty about the assigned values for some countries, especially in low- and middle-income areas. 


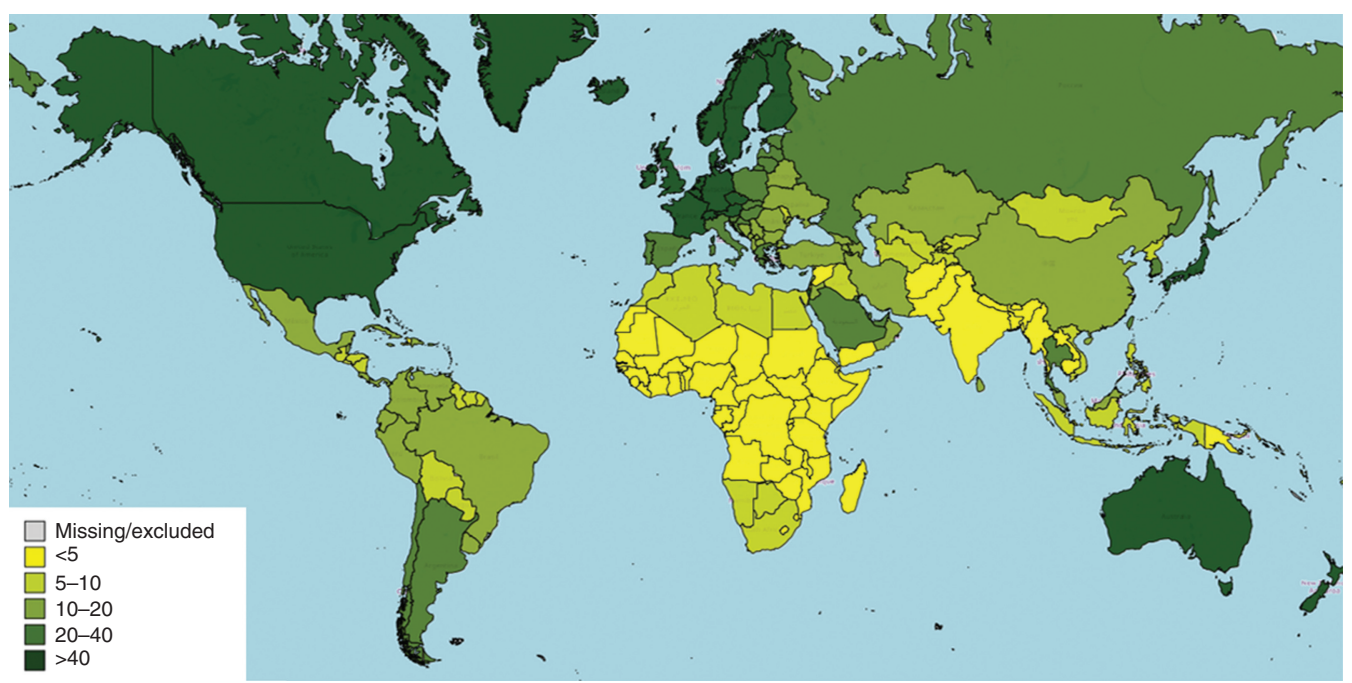

Figure 1. Map of estimated age (in years) at midpoint of population immunity (AMPI) to hepatitis A by country in 2015.

However, regional trends are apparent. In many low-income countries, HAV continues to be highly endemic and most children contract the virus before their fifth birthday. In many highincome countries, the HAV infection rate has been so low for several decades that the AMPI now exceeds 40 years of age. Middle-income countries generally have an AMPI in middle childhood or adolescence.

Most of the world's lowest-income countries are located in sub-Saharan Africa. Lower-middle-income countries are also scattered across sub-Saharan Africa, South and Southeast Asia, and parts of Central America, Central Asia, the Middle East, and Oceania (World Bank 2017). Many of these low- and lower-middle-income countries have high HAV incidence rates. Nearly all adult residents of these countries became infected as very young children and developed lifelong immunity. However, the incidence rate is decreasing in lower-middle-income regions and may decrease in low-income areas during the coming decades as the countries' economies and infrastructure develop. The Millennium Development Goals (MDGs) launched in 2000 spelled out a poverty-reduction strategy that provided low-income countries and their partners with specific targets for improving population-level socioeconomic, environmental, and health metrics. Between 1990 and 2015, the percentage of the world's people living on less than $\$ 1.25$ per day dropped from $47 \%$ to $14 \%$, while access to an improved drinking water source increased from $76 \%$ to $91 \%$ (United Nations 2015a). The Sustainable Development Goals (SDGs) that will guide global development strategies between 2016 and 2030 promote further reductions in poverty and increases in access to water, sanitation, hygiene, vaccination, medication, clinical care, and other tools for health (United Nations 2015b). The SDG targets for water and sanitation may be especially important drivers of reduced HAV burden in lowerincome countries. Access to an improved sanitation facility only increased from $54 \%$ to $68 \%$ between 1990 and 2015, and rural areas continue to lag behind urban areas in both water and sanitation access (United Nations 2015a). Under the SDGs, access to utilities will increase and disparities between regions are expected to decrease.

As the HAV incidence rate decreases and a larger pool of young children avoid exposure to the virus, a growing number of children, adolescents, and young adults in lower-income countries will remain vulnerable to HAV into their school years and beyond. This trend is already being observed in some relatively wealthy urban 
K.H. Jacobsen

areas within lower-middle-income countries. For example, a study of 3683 military recruits from across India in 2010-2011 found that $>7 \%$ of these young adults remained susceptible to HAV (Kotwal et al. 2014). There may also be some small pockets of vulnerability to HAV emerging in higher-income urban areas of lower-middle-income countries in West Africa (Jacobsen 2014). This could indicate that an HAV epidemiological transition is starting in these regions. This shift toward a lower level of endemicity will likely be gradual, in part because HAV survives so well in water and soil (Sobsey et al. 1986). As this transition occurs, the number of cases of symptomatic hepatitis A in these countries is likely to increase.

At present, the lowest-income countries are not major exporters of food, so they are playing a limited role in trade-related HAV exportation. As these countries' economies grow, they may become food exporters and play a greater role in foodborne outbreaks of HAV in other world regions. Low-income countries already receive a sizeable number of international travelers, including tourists and heritage visitors as well as business travelers, and the number of international guests will increase in the coming years. If these travelers are not protected against HAV by vaccination or prior infection, they are likely to contract the virus and bring it home.

The world's highest-income countries are located primarily in Europe, North America, and Australasia, and they are also found in parts of the Middle East and East Asia, including Japan and the Republic of Korea (World Bank 2017). HAV is not endemic in these areas, and because these countries have had very low incidence rates for several decades they have populations that are highly susceptible to hepatitis A. The number and magnitude of outbreaks of hepatitis A is likely to increase somewhat as a result of globalization processes. Travel vaccines prevent hepatitis A cases in international travelers and limit the number of secondary cases that could occur among the contacts of infected travelers. However, most hepatitis A cases in highincome countries occur among people who have not traveled internationally in the months before the onset of symptoms (Gossner et al. 2015;
CDC 2017). Few adults who live in high-income countries have been vaccinated against HAV, and a large proportion of older adults remain susceptible to HAV (Jacobsen and Wiersma 2010). Outbreaks from imported foods can affect hundreds or thousands of people, and infected adults may miss many weeks of work and require costly hospitalizations. Large, expensive multicountry outbreaks of hepatitis A attributable to imported foods are occurring more frequently than they did in previous decades (Gossner et al. 2015; Tavoschi et al. 2015). If hepatitis A outbreaks become more common, it may be helpful for economists to examine the potential value of hepatitis A vaccination for protecting members of the workforce in high-income countries from the lengthy absences that could be caused by severe acute hepatitis.

The world's middle-income countries are located in Central and South America, East Asia, and parts of North Africa, the Middle East, Central Asia, Southeast Asia, Southern Africa, and Eastern Europe (World Bank 2017). Middle-income countries have diverse patterns for HAV, with even small differences in economic status linked to different HAV profiles. The AMPI is shifting into adolescence and early adulthood in many countries, but there are often significant rural-urban and other differences within subpopulations (Van Effelterre et al. $2017 a, b)$. For example, there is an east-to-west gradient of decreasing levels of HAV endemicity in Turkey (Demiray et al. 2016) and a north-tosouth gradient of lowering risk in Brazil (Ximenes et al. 2014). Geographic differences in risk have also been observed in other uppermiddle-income countries.

Middle-income countries are the places where universal childhood vaccination is most likely to be recommended, because there is still a moderate risk of infection for residents through contaminated food, water treatment system failures, intracountry travel to rural areas, and other exposures, and the increasing AMPI means that many of the people who contract HAV are old enough to be at risk of acute liver failure. In upper-middle-income countries, universal childhood vaccination against hepatitis $\mathrm{A}$ is often 
found to be a cost-effective public health intervention (Suwantika et al. 2013), in addition to protecting vaccinated children and the adults in their families from the direct and indirect household costs associated with infection. For example, cost-effectiveness analyses have suggested that universal childhood vaccination would be a good investment in countries as diverse as Brazil (Sartori et al. 2012), Indonesia (Suwantika et al. 2014), and Mexico (Carlos et al. 2016). Routine childhood vaccination against hepatitis A has already been introduced in several middleincome countries (WHO 2017).

Middle-income countries play an important role in the global epidemiology of HAV, and they are likely to continue to play a key role in global transmission cycles. Many middle-income countries are food exporters, and they are implicated in a growing number of foodborne outbreaks in higher-income countries. They also are a common destination for international travelers, and the number of flights between highincome and middle-income countries is increasing. As middle-income countries' economies grow, they are likely to switch from being countries that are distributing HAV to other world regions to being nonendemic countries that are vulnerable to HAV outbreaks sparked by international trade and travel originating in lowerincome regions.

\section{CONCLUDING REMARKS}

Pandemics of infectious diseases began occurring soon after global trade routes opened in the 16 th century. By the early 1800s, widespread cholera outbreaks were occurring in waves (Lee and Dodgson 2000). Starting in 1851, a series of International Sanitary Conferences were convened to establish infectious disease prevention regulations that would protect public health while allowing international trade to continue (Huber 2006). The resulting International Sanitary Regulations formed the foundation for the International Health Regulations that guide global communication about shared threats to health today. Global trade is even more critical for the economic security of countries around the world today than it was when the original international health treaties were negotiated. Even when countries adopt nationalist policies that seek to limit some aspects of international commerce and migration, it would be impossible and unwise to attempt to block all food imports and stop all international travel (including travel by diplomats and other government officials, military personnel, and other people whose work is critical to national interests). In a globalized world, pathogens easily spread between places and populations. No country will be able to completely eliminate its risk from hepatitis A while HAV remains endemic in any part of the world.

Although the trends in hepatitis A epidemiology point to a steadily decreasing incidence rate at the global level, the distribution of risk is not uniform. The lowest-income countries have a high incidence rate but a low disease burden. The highest-income countries have a very low incidence rate, but the individuals who become infected have a high likelihood of requiring hospitalization and a risk of death from acute liver failure. Middle-income countries that are transitioning toward nonendemic status may temporarily experience an increased burden from severe hepatitis as the age at infection increases. The epidemiological changes in hepatitis $\mathrm{A}$ that occur in countries across the income spectrum in the coming decades will be heavily influenced by globalization processes.

\section{REFERENCES}

Acheson D, Fiore AE. 2004. Hepatitis A transmitted by food. Clin Infect Dis 38: 705-715.

Advisory Committee on Immunization Practices (ACIP); Fiore AE, Wasley A, Bell BP. 2006. Prevention of hepatitis A through active or passive immunization: Recommendations of the Advisory Committee on Immunization Practices (ACIP). MMWR Recomm Rep 55: 1-23.

Barnett ED, MacPherson DW, Stauffer WM, Loutan L, Hatz CF, Matteelli A, Behrens RH. 2010. The visiting friends or relatives traveler in the 21st century: Time for a new definition. J Travel Med 17: 163-170.

Berge JJ, Drennan DP, Jacobs RJ, Jakins A, Meyerhoff AS, Stubblefield W, Weinberg M. 2000. The costs of hepatitis A infections in American adolescents and adults in 1997. Hepatology 31: 469-473.

Boggild AK, Castelli F, Gautret P, Torresi J, von Sonnenburg F, Barnett ED, Greenaway CA, Lim PL, Schwartz E, Wilder-Smith A, et al. 2010. Vaccine preventable diseases in 
K.H. Jacobsen

returned international travelers: Results from the GeoSentineal Surveillance Network. Vaccine 28: 7389-7395.

Bui YG, Trépanier S, Milord F, Blackburn M, Provots S, Gagnon S. 2011. Cases of malaria, hepatitis A, and typhoid fever among VFRs, Quebec (Canada). J Travel Med 18: 373-378.

Carlos F, Gómez JA, Anaya P, Romano-Mazzotti L. 2016. Health economic assessment of universal immunization of toddlers against hepatitis A virus (HAV) in Mexico. Hum Vaccin Immunother 12: 52-63.

Carrillo-Santisteve P, Tavoschi L, Severi E, Bonfigli S, Edelstein M, Byström E, Lopalco P, ECDC HAV Expert Panel. 2017. Seroprevalence and susceptibility to hepatitis A in the European Union and European Economic Area: A systematic review. Lancet Infect Dis 17: e306-e319.

Chin BS, Kim JY, Gianella S, Lee M. 2016. Travel pattern and prescription analysis at a single travel clinic specialized for yellow fever vaccination in South Korea. Infect Chemother 48: $20-30$.

Collier MG, Khudyakov YE, Selvage D, Adams-Cameron M, Epson E, Cronquist A, Jervis RH, Lamba K, Kimura AC, Sowadsky R, et al. 2014. Outbreak of hepatitis A in the USA associated with frozen pomegranate arils imported from Turkey: An epidemiological case study. Lancet Infect Dis 14: 976-981.

Demiray T, Köroğlu M, Jacobsen KH, Özbek A, Terzi HA, Altindiș M. 2016. Hepatitis A virus epidemiology in Turkey as universal childhood vaccination begins: Seroprevalence and endemicity by region. Turk J Pediatr 58: 480491.

Donnan EJ, Fielding JE, Gregory JE, Lalor K, Rowe S, Goldsmith P, Antoniou M, Fullerton KE, Knope K, Copland JG, et al. 2012. A multistate outbreak of hepatitis A associated with semidried tomatoes in Australia, 2009. Clin Infect Dis 54: 775-781.

Gossner CM, Severi E. 2014. Three simultaneous, foodborne, multi-country outbreaks of hepatitis A virus infection reported in EPIS-FWD in 2013: What does it mean for the European Union? Euro Surveill 19: 20941.

Gossner CM, Severi E, Danielsson N, Hutin Y, Coulombier D. 2015. Changing hepatitis A in the European Union: New challenges and opportunities. Euro Surveill 20: 21101.

Gould LH, Kline J, Monahan C, Vierk K. 2017. Outbreaks of disease associated with food imported into the United States, 1996-2014. Emerg Infect Dis 23: 525-528.

Greig JD, Ravel A. 2009. Analysis of foodborne outbreak data reported internationally for source attribution. Int J Food Microbiol 130: 77-87.

Gushulak BD, MacPherson DW. 2000. Population mobility and infectious diseases: The diminishing impact of classical infectious diseases and new approaches for the 21st century. Clin Infect Dis 31: 776-780.

Halliday ML, Kang LY, Zhou TK, Hu MD, Pan QC, Fu TY, Huang YS, Hu SL. 1991. An epidemic of hepatitis A attributable to the ingestion of raw clams in Shanghai, China. J Infect Dis 164: 852-859.

Heywood AE, Nothdurft H, Tessier D, Moodley M, Rombo L, Marano C, De Moerlooze L. 2016. Pre-travel advice, attitudes and hepatitis $\mathrm{A}$ and $\mathrm{B}$ vaccination rates among travelers from seven countries. J Travel Med 24: taw069.
Huber V. 2006. The unification of the globe by disease? The international sanitary conferences on cholera, 18511894. Hist J 49: 453-476.

Huynen MMTE, Martens P, Hilderink HBM. 2005. The health impacts of globalization: A conceptual framework. Global Health 1: 14.

Itani T, Jacobsen KH, Nguyen T, Wiktor SZ. 2014. A new method for imputing country-level estimates of hepatitis A virus endemicity levels in the Eastern Mediterranean region. Vaccine 32: 6067-6074.

Jacobsen KH. 2009. The global prevalence of hepatitis A virus infection and susceptibility: A systematic review. World Health Organization, Geneva, Switzerland.

Jacobsen KH. 2014. Hepatitis A virus in West Africa: Is an epidemiological transition beginning? Nigerian Med J 55: 279-284.

Jacobsen KH, Koopman JS. 2004. Declining hepatitis A seroprevalence: A global review and analysis. Epidemiol Infect 132: 1005-1022.

Jacobsen KH, Koopman JS. 2005. The effects of socioeconomic development on worldwide hepatitis A virus seroprevalence patterns. Int J Epidemiol 34: 600-609.

Jacobsen KH, Wiersma ST. 2010. Hepatitis A virus seroprevalence by age and world region, 1990 and 2005. Vaccine 28: 6653-6657.

Jerardo A. 2016. Table 1: Import share of U.S. food consumption. In Import share of consumption. USDA Economic Research Service, Washington, DC.

Käferstein FK, Motarjemi Y, Bettcher DW. 1997. Foodborne disease control: A transnational challenge. Emerg Infect Dis 3: 503-510.

Kirk MD, Pires SM, Black RE, Caipo M, Crump JA, Devleesschauwer B, Döpfer D, Fazil A, Fischer-Walker CL, Hald T, et al. 2015. World Health Organization estimates of the global and regional disease burden of 22 foodborne bacterial, protozoal, and viral disease, 2010: A data synthesis. PLoS Med 12: e1001940.

Klevens RM, Kruszon-Moran D, Wasley A, Gallagher K, McQuillan GM, Kuhnert W, Teshale EH, Drobeniuc J, Bell BP. 2011. Seroprevalence of hepatitis A virus antibodies in the U.S.: Results from the National Health and Nutrition Examination Survey. Public Health Rep 126: 522-532.

Koroglu M, Jacobsen KH, Demiray T, Ozbek A, Erkorkmaz U, Altindis M. 2017. Socioeconomic indicators are strong predictors of hepatitis A seroprevalence rates in the Middle East and North Africa. J Infect Public Health 10: 513517.

Kotwal A, Singh H, Verma AK, Gupta RM, Jain S, Sinha S, Joshi RK, Teli P, Khunga V, Bhatnagar A, et al. 2014. A study of hepatitis A and E seropositivity amongst young healthy adults in India. Med J Armed Forces India 70: 225-229.

Kurkela S, Pebody R, Kafatos G, Andrews N, Barbar C, Bruzzone B, Butur D, Caplinskas S, Davidkin I, Hatzakis A, et al. 2012. Comparative hepatitis A seroepidemiology in 10 European countries. Epidemiol Infect 140: 2172-2181.

Lammert SM, Rao SR, Jentes ES, Fairley JK, Erskine S, Walker AT, Hagmann SH, Sotir MJ, Ryan ET, LaRocque RC. 2017. Refusal of recommended travel-related vaccines 
among U.S. international travelers in Global TravEpiNet. J Travel Med 24: taw075.

Lazcano-Ponce E, Conde-Gonzalez C, Rojas R, DeAntonio R, Romano-Mazzotti L, Cervantes Y, Ortega-Barria. 2013. Seroprevalence of hepatitis A virus in cross-sectional study in Mexico: Implications for hepatitis A vaccine. Hum Vaccin Immunother 9: 375-381.

Leder K, Torresi J, Libman MD, Cramer JP, Castelli F, Schlagenhauf $\mathrm{P}$, Wilder-Smith A, Wilson ME, Keystone JS Schwartz E, et al. 2013. GeoSentinel surveillance of illness in returned travelers, 2007-2011. Ann Intern Med 158: 456-468.

Lee K, Dodgson R. 2000. Globalization and cholera: Implications for global governance. Glob Gov 6: 213-236.

Lee D, Ki M, Lee A, Lee KR, Park HB, Kim CS, Yoon BY, Kim JH, Lee YS, Jeong SH. 2011. A nationwide seroprevalence of total antibody to hepatitis A virus from 2005 to 2009: Age and area-adjusted prevalence rates. Korean J Hepatol 17: 44-50.

Lu J, Zhou Y, Lin X, Jiang Y, Tian R, Zhang Y, Wu J, Zhang F, Zhang Y, Wang Y, et al. 2009. General epidemiological parameters of viral hepatitis $\mathrm{A}, \mathrm{B}, \mathrm{C}$, and $\mathrm{E}$ in six regions of China: A cross-sectional study in 2007. PLoS ONE 4: e8467.

Mellou K, Chrisostomou A, Sideroglou T, Georgakopoulou T, Kyritsi M, Hadjichristodoulou C, Tsiodras S. 2017. Hepatitis A among refugees, asylum seekers and migrants living in hosting facilities, Greece, April to December 2016. Euro Surveill 22: 30448.

Michaelis K, Wenzel JJ, Stark K, Faber M. 2017. Hepatitis A virus infections and outbreaks in asylum seekers arriving to Germany, September 2015 to March 2016. Emerg Microbes Infect 6: 326 .

Mohd Hanafiah K, Jacobsen KH, Wiersma ST. 2011. Challenges to mapping the health risk of hepatitis A virus infection. Int J Health Geogr 10: 57.

Namikawa K, Iida T, Ouchi K, Kimura M. 2010. Knowledge, attitudes, and practices of Japanese travelers on infectious disease risks and immunization uptake. J Travel Med 17: 171-175.

Pedersini R, Marano C, De Moerlooze L, Chen L, Vietri J. 2016. HAV and HBV vaccination among travelers participating in the National Health and Wellness Survey in five European countries. Travel Med Infect Dis 14: 221232.

Rein DB, Stevens G, Flaxman A, Wittenborn JS, Timothy N, Wiktor SZ, Wiersma ST. 2014. The global burden of hepatitis A virus in 1990 and 2005. J Hepatol 60: S303.

Sa-nguanmoo P, Posuwan N, Vichaiwattana P, Vuthitanachot V Saelao S, Foonoi M, Fakthongyoo A, Makaroon J, Srisingh K, Asawarachun D, Owatanapanich S, et al. 2016. Declining trend of hepatitis A seroepidemiology in association with improved public health and economic status of Thailand. PLoS ONE 11: e0151304.

Sartori AMC, de Soárez PC, Novaes HMD, Amaku M, de Azevedo RS, Moreira RC, Pereira LMMB, Ximenes RAA, Martelli CMT. 2012. Cost-effectiveness analysis of universal childhood vaccination in Brazil: Regional analyses according to the endemic context. Vaccine 30: 7489-7497.

Semenza JC, Lindgren E, Balkanyi L, Espinosa L, Almqvist MS, Penttinen P, Rocklöv J. 2016. Determinants and driv- ers of infectious disease threat events in Europe. Emerg Infect Dis 22: 581-589.

Severi E, Verhoef L, Thornton L, Guzman-Herrador BR, Faber M, Sundqvist L, Rimhanen-Finne R, Roque-Afonso AM, Ngui SL, Allerberger F, et al. 2015. Large and prolonged food-borne multistate hepatitis A outbreak in $\mathrm{Eu}$ rope associated with consumption of frozen berries, 2013 to 2014. Euro Surveill 20: 21192.

Sobsey MD, Shields PA, Hauchman FH, Hazard RL, Caton LW III. 1986. Survival and transport of hepatitis A virus in soils, groundwater and wastewater. Water Sci Technol 18: 97-106.

Staes CJ, Schlenker TL, Risk I, Cannon KG, Harris H, Pavia AT, Shapiro CN, Bell BP. 2000. Sources of infection among persons with acute hepatitis $\mathrm{A}$ and no identified risk factors during a sustained community-wide outbreak. Pediatrics 106: e54.

Suk JE, Van Cangh T, Beauté J, Bartels C, Tsolova S, Pharris A, Ciotti M, Semenza JC. 2014. The interconnected and cross-border nature of risks posed by infectious disease. Glob Health Action 7: 25287.

Suwantika AA, Yegenoglu S, Riewpaiboon A, Tu HA, Postma MJ. 2013. Economic evaluations of hepatitis A vaccination in middle-income countries. Expert Rev Vaccines 12: 1479-1494.

Suwantika AA, Beutels P, Postma MJ. 2014. Cost-effectiveness of hepatitis A vaccination in Indonesia. Hum Vaccin Immunother 10: 2342-2349.

Swinkels HM, Kuo M, Embree G; Fraser Health Environmental Health Investigation Team; Andonov A, Henry B, Buxton JA. 2014. Hepatitis A outbreak in British Columbia, Canada: The roles of established surveillance, consumer loyalty cards and collaboration, February to May 2012. Euro Surveill 19: 20792.

Tavoschi L, Severi E, Niskanen T, Boelaert F, Rizzi V, Liebana E, Gomes Dias J, Nichols G, Takkinen J, Coulombier D. 2015. Food-borne diseases associated with frozen berries consumption: A historical perspective, European Union, 1983 to 2013. Euro Surevill 20: 21193.

UNICEF/WHO. 2015. Progress on sanitation and drinking water: 2015 update and MDG assessment. World Health Organization, Geneva.

United Nations (UN). 2015a. The millennium development goals report 2015. United Nations, New York.

United Nations (UN). 2015b. Transforming our world: The 2030 agenda for sustainable development. United Nations, New York.

United Nations Department of Economic and Social Affairs (UN DESA). 2016. International migration report 2015. United Nations, New York.

United Nations Department of Economic and Social Affairs (UN DESA). 2017. World population prospects 2017. United Nations, New York.

United States Centers for Disease Control and Prevention (CDC). 2017. Surveillance for viral hepatitis-United States, 2015. CDC, Atlanta.

Van Effelterre TP, Guignard A, Marano C, Rojas R, Jacobsen KH. 2017a. Modeling the hepatitis A epidemiological transition in Brazil and Mexico. Hum Vacc Immunother 13: $1942-1951$. 
K.H. Jacobsen

Van Effelterre TP, Marano C, Jacobsen KH. 2017b. Modeling the hepatitis A epidemiological transition in Thailand. Vaccine 34: 555-562.

van Genderen PJJ, van Thiel PPAM, Mulder PGH, Overbosch D; Dutch Schiphol Airport Study Group. 2012. Trends in knowledge, attitudes, and practices of travel risk groups toward prevention of hepatitis A: Results from the Dutch Schiphol airport survey 2002 to 2009. J Travel Med 19: 35-43.

Wheeler C, Vogt TM, Armstrong GL, Vaughan G, Weltman A, Nainan OV, Dato V, Xia G, Waller K, Amon J, et al. 2005. An outbreak of hepatitis A associated with green onions. N Engl J Med 353: 890-897.

World Bank. 2017. World development indicators 2017. World Bank, Washington, DC.

World Health Organization (WHO). 2012. WHO position paper on hepatitis A vaccines-June 2012. Wkly Epidemiol Rec 87: 261-276.
World Health Organization (WHO). 2017. WHO vaccinepreventable diseases: Monitoring system-2017 global summary. World Health Organization, Geneva.

World Tourism Organization (UNWTO). 2016. UNWTO tourism highlights, 2016 edition. UNWTO, Madrid, Spain.

Ximenes RA, Martelli CM, Amaku M, Sartori AM, de Soárez PC, Novaes HM, Pereira LM, Moreira RC, Figueiredo GM, de Azevedo RS, et al. 2014. Modelling the force of infection for hepatitis A in an urban population-based survey: A comparison of transmission patterns in Brazilian macro-regions. PLoS ONE 9: e94622.

Yanez LA, Lucero NS, Barril PA, Díaz MP, Tenaglia MM, Spinsanti LI, Nates SV, Isa MB, Ré VE. 2014. Evidence of hepatitis A virus circulation in central Argentina: Seroprevalence and environmental surveillance. J Clin Virol 59: $38-43$. 


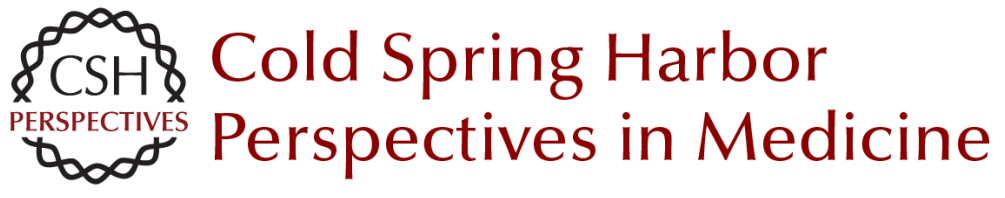

\section{Globalization and the Changing Epidemiology of Hepatitis A Virus}

Kathryn H. Jacobsen

Cold Spring Harb Perspect Med 2018; doi: 10.1101/cshperspect.a031716 originally published online March 2, 2018

\section{Subject Collection Enteric Hepatitis Viruses}

Hepatitis A Virus Genome Organization and Replication Strategy

Kevin L. McKnight and Stanley M. Lemon

Adaptive Immune Responses in Hepatitis A Virus and Hepatitis E Virus Infections

Christopher M. Walker

Small Animal Models of Hepatitis E Virus Infection Tian-Cheng Li and Takaji Wakita

Acute and Persistent Hepatitis E Virus Genotype 3 and 4 Infection: Clinical Features, Pathogenesis, and Treatment Nassim Kamar and Sven Pischke

Epidemiology of Genotype 1 and 2 Hepatitis E Virus Infections

Kenrad E. Nelson, Alain B. Labrique and Brittany L. Kmush

History of the Discovery of Hepatitis A Virus Stephen M. Feinstone

Epidemiology and Transmission of Hepatitis A Virus and Hepatitis E Virus Infections in the United States

Megan G. Hofmeister, Monique A. Foster and Eyasu H. Teshale

Stem Cell-Derived Culture Models of Hepatitis E Virus Infection

Viet Loan Dao Thi, Xianfang Wu and Charles M. Rice
Evolutionary Origins of Enteric Hepatitis Viruses Anna-Lena Sander, Victor Max Corman, Alexander N. Lukashev, et al.

Enterically Transmitted Non-A, Non-B Hepatitis and the Discovery of Hepatitis E Virus

Stanley M. Lemon and Christopher M. Walker

Natural History, Clinical Manifestations, and

Pathogenesis of Hepatitis E Virus Genotype 1 and

2 Infections

Rakesh Aggarwal and Amit Goel

Hepatitis A Virus and Hepatitis E Virus: Emerging and Re-Emerging Enterically Transmitted

Hepatitis Viruses

Stanley M. Lemon and Christopher M. Walker

Hepatitis A Virus Capsid Structure

David I. Stuart, Jingshan Ren, Xiangxi Wang, et al.

Comparative Pathology of Hepatitis A Virus and Hepatitis E Virus Infection John M. Cullen and Stanley M. Lemon

Innate Immunity to Enteric Hepatitis Viruses Zongdi Feng and Stanley M. Lemon

Nonhuman Primate Models of Hepatitis A Virus and Hepatitis E Virus Infections

Robert E. Lanford, Christopher M. Walker and

Stanley M. Lemon

For additional articles in this collection, see http://perspectivesinmedicine.cshlp.org/cgi/collection/ 